\title{
Football Talent Development Stages from the Viewpoint of Complexity Theory
}

\author{
Ji-Hun Kang \& Young-Kil Yun* \\ Korea National Sport University
}

\begin{abstract}
[Purpose] This study was aimed at interpreting the football talent development stages based on complexity theory. [Methods] The data for this study was gathered through literature review and in-depth interviews that were analyzed by thematic analysis. Literature review of the studies regarding complexity theory revealed the features of complexity theory and five football players participating in the K-league were interviewed. Gathered materials were analyzed by the thematic analysis. Initial codes and potential themes of football talent development stages, the conception and potential themes of the complexity theory were interpreted by metaphorical analysis. [Results] Results of literature review were as follows: analysis frame of complexity theory were organized environment of complexity, feedback structure, self-organization, critical condition and emergent phenomenon. The football talent development stages, interpreted as a result of literature review, were divided into Potential Talents, Excellence based Talents Development, Footballizational Talents, Football to Takeoff and Personalization of Football Talents. The stages were specifically materialized as follows: Potential Talents was materialized into physical condition, physical activity preference and change of environment. Excellence based Talent Development was materialized into skill mastery, thoughts about football and relationship with significant others. Footballizational Talents was materilized into skill fractionation, football flow and growth experience. Football to Takeoff was materialized into overcoming crisis experience, performance scaffolding and performance takeoff. Personalization of Football Talents was materialized into manifestation of performance personalization, performance evolution, condition maintenance. [Conclusions] Football talent development stages, interpreted by means of complexity theory, were divided into Potential Talents stage, Excellence based Talent Development stage, Footballizational Talents stage, Football to Takeoff stage and Personalization of Football Talents stage. Utilization of this study as a fundamental resource of football talents development programs and as a means to understanding football talents development is looked forward to.
\end{abstract}

Key words: Football talent development stages, Development stages, Football talent, Complexity theory, Football

\section{서 론 \\ 대한축구협회는 2014년부터 골든에이지 프로젝트를 제 도화해 축구선수의 재능발달을 지원하고 있다. 축구선수의}

논문 투고일 : 2020. 11. 22.

논문 수정일 : 2021. 03. 03.

게재 확정일 : 2021. 03. 19.

* 교신저자 : 윤영길(ykyun@knsu.ac.kr)

* 강지훈의 석사학위 논문(2015)을 토대로 작성함
재능발달에 대한 관심은 훈련프로그램 개발(Kim et al., 2002), 선수 재능발달 훈련 프로그램 개발(KFA, 2014), 지 도자 교육 프로그램(KFA, 2019) 등 대한축구협회 차원에서 이어져 왔다. 여기에 아시아축구연맹(AFC)의 Elite Youth Scheme Programme, 국제축구연맹(FIFA)의 Grassroots Programme이나 Legends Programme이 진행되는 등 축구재능발달은 축구계 공통의 관심사이다. 이러한 관심은 축구재능과 축구재능발달 이해를 촉진하는 동시에 선수 훈 
련프로그램 풍부화에 기여해왔다.

축구선수의 재능발달은 인간 발달 맥락에서 이해할 수 있 다. 이러한 인간 발달은 발달에 관여된 요소의 총체적 과정 (Chung, 2001)으로 개인의 내적 특성부터 문화까지 영향 요인의 상호작용 양상(Ericsson et al., 1993; Song \& Yoo, 2011)에 따라 다르게 구현된다(Chung, 2004). 인간 발달에 영향을 미치는 요인의 특징이나 영향력 등에 따라 발 달과 발달과정에 대한 관심이 다양하게 전개되어왔다. 발달 에 대한 관심의 차이는 발달을 설명하는 방략의 차이로 이어 져 인지, 도덕성, 언어, 운동 등 다양한 분야의 발달이나 발 달 단계를 설명하는 이론으로 정교화되었다.

발달 단계를 내용으로 하는 이론 체계는 해당 분야나 영 역의 발달에 대한 포괄적 이해를 제공하고 있다. 실제로 인 지발달이론(Piaget, 1936)에서는 인지발달을 감각운동기, 전조작기, 구체적 조작기, 형식적 조작기로 단계화해 인간 의 인지적 성숙의 과정을 설명하고 있다. 이러한 구분은 인 지발달 단계에 대한 이해는 물론 아동관의 패러다임 전환을 이끌었다. 또한 도덕발달이론(Kohlberg, 1963)에서는 도 덕적 갈등 상황인 하인츠 딜레마(Heinz's dilemma)의 해 결 방식을 통한 도덕발달 단계를 추론해 도덕발달 단계에 대 한 이해를 제공했으며, 심리사회발달이론(Erikson, 1964) 에서는 발달에 영향을 미치는 사회문화적 요소를 반영하였 다. 이러한 통찰은 발달 단계나 발달 과정에서 나타나는 개 별요소와 요소 간 상호작용에 대한 통합적 이해의 필요성을 환기시켰다.

재능발달 과정은 개인의 발달처럼 재능과 사회문화적 요 인이 복잡하게 상호작용하면서 발달한다(Mills et al., 2012; Orosz \& Mezo, 2015). 이처럼 재능발달의 적확한 이해를 위해서는 재능 구성 요소나 구성 요소의 상호작용은 물론 재능발달 촉진 프로그램 등 재능발달 과정에 대한 전반 적 고려가 필요하다. 실제로 재능발달은 재능에 영향을 미 치는 요소와 요소 간 상호작용(Phillips et al., 2010) 결과 이다. 인간의 재능은 특정 영역에서 체계적인 훈련을 통해 발현된 성취(Gagné, 1985)로 재능의 발현에서 개인의 노 력이 중시된다(Gagné, 2004). 이처럼 재능은 개인이 보유 한 자원과 환경이 적절한 방식으로 상호작용한 결과이다 (Sternberg, 1999).

선수의 운동재능은 구성요소 간의 복합적 상호작용이나 불연속적인 과정(Abbott et al., 2005)을 거치면서 발달해 간다(Burgess \& Naughton, 2010; Ericsson et al.,
1993). 이 과정에서 기술 전이가 일어나 선행 기술이 후행 기술에 영향을 미치기도 하고(Burgess \& Naughton, 2010; Helsen et al., 2000), 체력 등 일부 요인은 다른 재 능 요인의 전제 조건이 되기도 한다(Yun \& Lee, 2006). 이 과정에서 개인의 노력은 재능을 촉진(Côté, 1999)하고, 열 정은 재능의 촉매가 되기도 한다(Seong, 2009). 이처럼 재 능은 개인에 내재된 내적 자원(Renzulli, 2003; Yun, 2011)이 외적 환경(Yun \& Jeon, 2013)과 상호작용한 결 과로 발현된다.

한편, 축구는 맥락적 연속성이 중시되는 아날로그 종목으 로 재능발달에 개인의 내적 자원이나 외적 환경이 단계적으 로 영향을 미친다. 또한 다양한 요인이 발달에 매개하는데, 이 과정에서 스포츠에 특화된 내생적 영재성이 1 차 상전이 를 거쳐 축구에 특화된 재능으로, 축구에 특화된 재능은 2차 상전이를 통해 자기화 단계로 발달된다(Shin et al., 2013). 이러한 축구재능의 발달 과정에서 내적 자원이나 외적 환경 은 물론 가치나 평판(Yun, 2015), 팀의 가치, 동료와 상호작 용, 지도자 소통 등이 영향을 미친다(Yun \& Kim, 2017).

축구재능발달에는 연령에 따른 심리적 발달과업이 존재 (Yun, 2013)하고, 기술이 불연속적으로 발달해 비선형성 (Abbott et al., 2005)이 존재한다. 이러한 특징이 통합적 으로 반영되어 단계화나 상전이를 거치면서 불연속적으로 발달한다(Shin et al., 2013). 뿐만 아니라 재능발달에 성장 이나 성숙으로 인한 효과(Phillips et al., 2010)나 훈련의 영향(Burgess \& Naughton, 2010)은 물론 개인을 둘러싼 지도자나 주요타자 등의 외적 환경(Yun \& Jeon, 2013) 등 이 영향을 미친다. 따라서 축구선수의 재능발달에서 나타나 는 복잡성, 불연속성, 상호작용 과정 등을 통합적으로 반영 할 수 있다면 축구재능발달에 대한 이해의 폭과 깊이를 확대 할 수 있을 것이다.

한편, 복잡계이론(Complexity Theory)은 구성요소로 설명되지 않는 요소의 설명(Gell-Mann, 1995), 창발현상 (Youn \& Chai, 2005) 등 복잡함 속에서 나타나는 규칙성 을 기반으로 대상을 설명한다. 복잡계이론에서는 구성요소 의 상호작용으로 인해 특정현상이 발현(Choi \& Park, 2007)되는 과정과 결과를 중시한다. 또한 대상의 설명 과정 에서 융통성과 개방성(Byun, 2011; Im \& Park, 2012), 사 회현상의 비선형적 상호작용(Kim \& Lee, 2007; Lee \& Jang, 2004)이 반영된다. 동시에 복잡계이론은 복잡한 문제 를 직관적으로 설명하고(Youn \& Chai, 2005), 구성요소 
간 관계를 반영한 통합적 이해를 제공한다(Singer, 1995).

복잡계이론에서는 대상의 설명을 위해 다음의 구성요소 를 단계적으로 도입한다. 먼저 환경복잡성(Youn \& Chai, 2005)에서는 현상에 대해 초기의 작은 차이와 체계의 혼란 자체를 반영한다. 이어지는 환류구조(Lee \& Jang, 2004; Youn \& Chai, 2005)에서는 일정 수준 이상의 에너지가 축적된다. 다음 자기조직성(Byun, 2011; Youn \& Chai, 2005)에서는 체계의 구조가 형성된다. 임계조건(Im \& Park, 2012)에서는 특정 사건과 결합하면서 비가역적 전환 이 일어난다. 마지막으로 창발현상(Youn \& Chai, 2005) 에서는 요소 간의 상호작용 결과가 시간의 흐름에 따라 에너 지 누적으로 발현된다.

이처럼 복잡계이론에서는 구성요소의 상호작용에 따른 진 화 과정(Whitesides \& Ismagilov, 1999)이나 구성요소 간 간섭에 따른 패턴 형성과 패턴의 환류구조(Arthur, 1999)를 담고 있다. 이러한 특징으로 복잡계이론은 학습과정의 단계 화(You, 2006), 사회현상의 변화 과정(Lee \& Jang, 2004; Shim et al., 2002), 정책체제의 형성과정(Kim, 2009b), 패 션디자인 적용가능성(Im \& Park, 2012) 등의 연구에서 비 선형성을 분석하는 틀로 도입되고 있다. 한편, 발달에서 개인 의 재능과 환경의 상호작용 결과는 비선형적(Abbott et al., 2005; Phillips et al., 2010)으로 발현된다. 실제로 축구선 수의 재능발달 역시 복잡한 요소가 상호작용하면서 비선형적 으로 진행될 개연성이 있어, 복잡계이론은 축구재능발달 단 계 이해에 분석 틀로 기능할 개연성이 있다.

이상에 따라 본 연구는 복잡계이론을 통해 축구재능 발달 단계를 해석할 목적으로 진행하였다. 이를 위해 첫 째, 복잡계이론의 이론 틀을 검토하여 축구재능발달 단 계의 분석 틀을 구성하였다. 둘째, 구성한 복잡계이론의 분석 틀을 적용하여 축구재능발달 단계를 해석하였다. 본 연구가 축구재능발달에 대한 총체적 이해에 기여하 는 동시에, 축구계에서 진행하는 축구재능발달 프로그 램의 기초자료로 활용되기를 기대해본다.

\section{연구방법}

\section{자료제공자}

본 연구에서는 $\mathrm{K}$ 리그 선수를 대상으로 심층면담을 진행
하였다. 자료제공자는 10 년 이상 선수 경력, 프로축구구단 에 입단해 1 년차 경기력 검증을 통과하면 2년차 계약이 진 행되는 현실을 감안하여 $\mathrm{K}$ 리그에서 최소 두 시즌 이상, $\mathrm{K}$ 리 그 경기 출장 경험 등 조건을 충족한 대상을 기준으로 5명을 대상으로 선정하였다. 자료제공자의 구체적 특징은 〈Table $1>$ 과 같다.

Table 1. Participants characteristics

\begin{tabular}{cl}
\hline \hline Participant(age) & \multicolumn{1}{c}{ Characteristics of participant } \\
\hline \multirow{3}{*}{$\mathrm{A}(27)$} & $\cdot$ Playing 14years, K league 4years, 79matches \\
& $\cdot$ 2008 University Challenge top Player \\
& $\cdot 2011$ Tryouts for K1, 2014 Playing K1 G-team \\
\hline \multirow{3}{*}{ K(25) } & $\cdot$ Playing 18years, K league 2years, 37matches \\
& $\cdot$ U-14, U-20 National Player \\
& $\cdot$ 2013 Tryouts for K2, 2014 Playing K1 G-team \\
\hline W(26) & $\cdot$ Playing 16years, K league 4years, 82matches \\
& $\cdot$ U-19, U-23 National Player \\
& $\cdot$ 2011 Tryouts for K1, 2014 Playing K1 S-team \\
\hline S(26) & $\cdot$ Playing 16years, K league 3years, 68matches \\
& $\cdot$ 2009 U-20 National Player \\
\hline \multirow{2}{*}{$\mathrm{H}(27)$} & $\cdot$ 2012 Tryouts for K1, 2014 Playing K1 I-team \\
\hline \hline & $\cdot$ Playing 17years, K league 4years, 94matches \\
& 2011 Tryouts for K1, 2014 Playing K1 S-team
\end{tabular}

\section{분석 틀로 복잡계이론}

축구재능은 선수의 입문기를 출발로 재능을 구현하면서 경기력 형성의 결과로 발달이 구체화된다. 이러한 재능발달 에는 발달과업은 물론 영향 요소의 복합적 상호작용이 불연 속적으로 영향을 미친다. 이 과정에 영향요소 상호 간의 역 동적인 상호작용 반영은 중요하다. 이를 감안하여 본 연구에 서는 축구재능발달 분석 틀로 복잡계이론을 활용하였다. 복 잡계이론의 분석 틀은 요인 간 상호작용, 불연속성, 시간의 흐름, 에너지의 축적 등의 개념을 도입해 현상을 설명한다. 현상의 설명 과정에서 시간의 흐름, 순차적 단계 변화 구조, 구성요소 간 융합적 상호작용 등의 계열이 구성된다(Byun, 2011; Im \& Park, 2012; Lee, 2014; Shim et al., 2002).

특정 현상의 발생이나 발생과정은 분야별로 다르게 나타 난다. 이러한 분야별 차이에도 불구하고 복잡계이론은 분야 를 아울러 보편적 분석 틀로 활용되고 있다. 실제로 물리학 에서는 초기조건과 시간의 방향, 요동, 복잡적응계, 공진화 등이 분석 틀(Gell-Mann, 1995)로, 교육학에서는 초기조 건의 민감성, 혼돈의 가장자리, 자기조직화와 공진화, 창발, 
프랙탈과 자기유사성, 양의 환류가 분석 틀(You, 2006)로, 정책분야에서는 사회현상의 비평형성, 비선형성, 공명의 장, 나비효과와 끌개, 분기점, 양의 환류, 프랙탈, 공진화가 분석 틀(Lee \& Jang, 2004)로 활용되고 있다. 문헌연구 결 과 복잡계이론은 분야에 따라 분석 틀의 구조를 달리하고 있 으며, 연구별 분석 틀의 구체적 내용은 〈Table 2 〉와 같다.

Table 2. Results of literature research

\begin{tabular}{|c|c|}
\hline Reference & Analysis frame \\
\hline You (2006) & $\begin{array}{l}\text { · sensitive dependency to initial · edge of chaos } \\
\text { · self-organization \& coevolution ·emergence } \\
\text { ·fractal \& self-similarity · positive feedback }\end{array}$ \\
\hline $\begin{array}{l}\text { Im \& Park } \\
\text { (2012) }\end{array}$ & $\begin{array}{l}\text { ·sensitive dependency to initial · non-linear \& } \\
\text { non-equilibrium · instability/irregularity \& } \\
\text { irreversibility · fractal \& self-similarity · dissipative } \\
\text { structure \& self-organization }\end{array}$ \\
\hline $\begin{array}{l}\text { Kim } \\
(2009 \mathrm{a} \\
2009 b)\end{array}$ & $\begin{array}{l}\text { ·self-organization · sensitive dependency to initial ·path } \\
\text { dependence · coevolution ·emergence }\end{array}$ \\
\hline $\begin{array}{l}\text { Shim et al. } \\
\text { (2002) }\end{array}$ & $\begin{array}{l}\cdot \text { resonace field } \cdot \text { bifurcation } \cdot \text { self-organization } \\
\text { · coevolution }\end{array}$ \\
\hline $\begin{array}{l}\text { Gell-Mann } \\
\text { (1995) }\end{array}$ & $\begin{array}{l}\cdot \text { intial condition \& arrow of time } \cdot \text { fluctuation } \\
\cdot \text { complex adaptive system · coevolution }\end{array}$ \\
\hline $\begin{array}{l}\text { Youn \& Chai } \\
\text { (2005) }\end{array}$ & $\begin{array}{l}\text { ·theory system of complexity · chaos \& strange attractor } \\
\text { ·fractal \& self-similarity · self-organization } \\
\text { ·critical phenomenon · complex adaptive system }\end{array}$ \\
\hline $\begin{array}{l}\text { Abbott et al. } \\
\text { (2005) }\end{array}$ & ·non-linear · dynamic · pathways \\
\hline $\begin{array}{l}\text { Jeong \& } \\
\text { Park (1999) }\end{array}$ & $\begin{array}{l}\text { ·non-equilibrium · non-linear · positive feedback } \\
\text { ·dissipative structure · self-organization } \\
\text { ·self-similarity \& coevolution }\end{array}$ \\
\hline Byun (2011) & $\begin{array}{l}\text { · meaning of complexity · self-organization ·emergence } \\
\text { ·attractor ·bifurcation ·coevolution }\end{array}$ \\
\hline $\begin{array}{l}\text { Lee \& Jang } \\
\quad(2004)\end{array}$ & $\begin{array}{l}\text { ·non-equilibrium } \cdot \text { non-linear } \cdot \text { resonace field } \\
\cdot \text { butterfly effect } \& \text { attractor } \cdot \text { bifurcation } \cdot \text { positive feedback } \\
\text { fractal } \cdot \text { coevolution }\end{array}$ \\
\hline
\end{tabular}

분야에 따라 다양한 요소로 구성되고 있음에도 불구하고 초기조건의 민감성, 비평형성, 양의 환류, 공진화, 자기조직 화, 분산구조, 임계점, 요동과 섭동, 창발, 자기유사성 등의 개념은 분야에 무관하게 보편적으로 도입되고 있다. 이러한 복잡계이론의 구성개념은 단계화, 발달과업, 재능요소의 상 호작용이나 영향력 등의 축구재능발달 특성을 고려하여 주 제분석으로 잠재주제를 〈Table 3)과 같이 도출하였다.
Table 3. Potential theme from thematic analysis

\begin{tabular}{cc}
\hline \hline Concepts & Potential theme \\
\hline $\begin{array}{c}\text { sensitive dependency to initial / } \\
\text { non-equilibrium }\end{array}$ & $\begin{array}{c}\text { environment of } \\
\text { complexity }\end{array}$ \\
\hline positive feedback / coevolution & feedback structure \\
\hline self-organization / dissipative structure & self-organizationity \\
\hline critical point / fluctuation \& perturbation & critical condition \\
\hline emergence / self-similarity & emerge phenomenon \\
\hline \hline
\end{tabular}

구체적으로 초기조건의 민감성과 비평형성은 환경복잡 성으로, 양의 환류와 공진화는 환류구조로, 자기조직화와 분산구조는 자기조직성으로, 요동과 섭동, 임계점은 임계조 건으로, 창발과 자기유사성은 창발현상으로 구조화하였다. 이상을 종합하면 축구재능발달의 분석 틀로 복잡계이론은 〈Fig 1〉과 같이 요약된다. 분석 틀은 연구진과 축구전문가 1 인, 스포츠심리학박사 3 인이 참가한 전문가회의를 통해 복잡계이론의 개념 체계나 개념 간 상호작용, 축구의 특징 등을 감안하여 〈Fig 1 〉의 개념과 개념의 연결인 실선을 축 구재능발달의 분석 틀로 채택하였다.

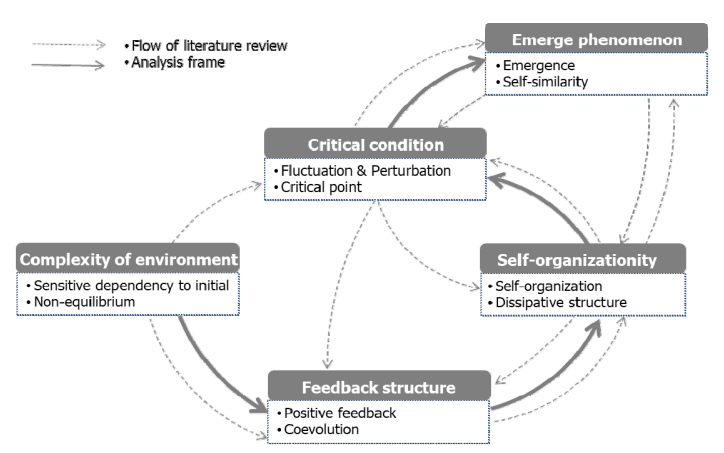

Fig 1. Analysis frame for football talent development

\section{조사도구}

본 연구는 문헌연구와 심층면담을 활용하여 진행하였다. 문헌연구를 위하여 논문검색 포털에서 KISS와 RISS에서 복잡계이론을 키워드로, Google scholar와 ebsco host에 서 Complexity theory를 키워드로 자료를 수집하였다.

심층면담은 〈Fig 1〉복잡계이론 분석 틀의 구성개념과 잠재주제를 토대로 축구선수 입문부터 현재까지의 단계를 반영한 질문 주제를 〈Table 4〉와 같이 추출해 심층면담 가 이드라인으로 제작하였다. 
Table 4. Interview guideline

\begin{tabular}{clc}
\hline \hline Potential theme & \multicolumn{1}{c}{ Theme } & $\begin{array}{c}\text { Development } \\
\text { stage }\end{array}$ \\
\hline $\begin{array}{c}\text { complexity of } \\
\text { environment }\end{array}$ & $\begin{array}{l}\text { motor neuron/ school record/ play \& } \\
\text { character/ started football }\end{array}$ & $\begin{array}{c}\text { player } \\
\text { introductory }\end{array}$ \\
\hline \multirow{2}{*}{$\begin{array}{l}\text { feedback } \\
\text { structure }\end{array}$} & $\begin{array}{l}\text { improvement of physical \& skills/ } \\
\text { training strategy/ attitude \& character/ } \\
\text { training environment(parents, coach, } \\
\text { peer) }\end{array}$ & intensive \\
training \\
self- & $\begin{array}{l}\text { know how/ competition strategy/ } \\
\text { difference of training \& competition/ } \\
\text { grganizationith experience }\end{array}$ & \\
\hline \multirow{2}{*}{$\begin{array}{l}\text { gritical condition } \\
\text { limitation of physical/ find football } \\
\text { enlightenment \& opportunity/ } \\
\text { overcoming crisis \& opportunity }\end{array}$} & $\begin{array}{c}\text { K league } \\
\text { debut }\end{array}$ \\
\hline $\begin{array}{c}\text { change play pattern/ exposure your style } \\
\text { emerge }\end{array}$ & $\begin{array}{l}\text { \& application/ applied play style/ } \\
\text { performance maintain/ training } \\
\text { environment }\end{array}$ & the present \\
\hline \hline
\end{tabular}

\section{연구 절차}

본 연구는 문헌연구, 심층면담, 결과분석, 결과창출 순으 로 진행하였다.

문헌연구는 복잡계이론의 내용 이해와 분석 틀을 도출하 기 위한 목적으로 진행하였다. 문헌연구 대상 문헌은 논문 검색 포털에서 선정하였으며, 선정된 문헌을 토대로 복잡계 이론의 구성개념을 추출하고 구성개념의 내용을 기준으로 잠재주제를 선정하였다. 잠재주제 선정에서는 내용의 단계 별 방향성과 구성개념의 상호작용을 감안하여 심층면담 가 이드라인을 제작하였다.

심층면담 단계에서 연구자는 자료제공자의 축구재능에 대한 맥락적 이해를 도모하기 위하여 자료제공자의 최근 세 경기 영상을 시청하였다. 심층면담을 위한 예비면담은 전화 로 진행하였다. 사전면담에서는 연구참여 동의를 확인하였 으며, 연구 참여에 동의한 자료제공자에게 연구 배경과 목 적을 설명하고 〈Table 4〉의 인터뷰 내용을 설명하여 심층 면담 전까지 숙고를 요청하였다. 심층면담에서는 자료제공 자의 숙소 인근 카페에서 서면동의서 작성, 결과의 익명성 보장과 자유로운 연구철회를 설명, 녹취 동의를 구하였으 며, 심층면담 가이드라인을 토대로 심층면담을 진행하였다. 심층면담은 축구선수를 시작한 시점부터 오늘까지 선수생 활을 회상하도록 하였으며, 55분-90분간 진행하였다. 자료 보완이 필요한 경우 추가면담이나 전화인터뷰로 자료를 보
완해 심층면담 녹취록을 제작하였다.

결과분석 단계에서는 심층면담 녹취록을 흔 글2014에 전 사하였으며, 전사한 자료는 주제분석을 활용하여 초기코드 와 잠재주제를 선정하였다. 주제분석은 다음의 단계로 진행 하였다. 우선 자료와 익숙해지기 단계에서는 복잡계이론과 축구재능발달 선행연구를 탐색하고 심층면담 녹취록을 숙 독하였다. 초기코드생성 단계에서는 복잡계이론 구성개념 단위 선정과 심층면담 녹취록을 분석하였다. 주제탐색 단계 에서는 초기코드를 잠재주제로 선정하였으며, 주제검토 단 계에서는 잠재주제 선정 과정이나 적절성을 검토해 복잡계 이론의 분석 틀을 시각화하였다. 주제선정 단계에서는 구성 개념, 초기코드, 잠재주제의 전체적인 흐름을 파악하였다. 마지막으로 선정한 자료를 최종적으로 검토해 연구결과를 도출하였다.

결과창출 단계에서는 문헌연구의 복잡계이론 분석 틀을 토대로 축구재능발달의 결과를 해석하였다. 결과 해석은 복 잡계이론의 구성개념과 축구재능발달의 초기코드를, 각각 의 잠재주제 단위를 해석하였으며, 해석과정에서 현상의 개 방성이나 시간의 흐름에 따라 변화하는 연속성을 고려 (Youn \& Chai, 2005)하였다. 축구재능발달 해석은 구성개 념 단위와 구성개념의 계열을 조직화(Byun, 2011; You, 2006; Youn \& Chai, 2005)해 분석할 수 있는 은유적 분석 을 활용하였다. 연구 과정에서 연구진과 스포츠심리학 박사 3 인, 축구전문가 1 인 등 6 인이 참석한 전문가회의를 개최해 분석 틀 구성과 연구결과 도출의 타당성을 검토하였다.

\section{자료 분석}

본 연구에서는 복잡계이론 분석 틀과 축구재능발달 구조 화에 주제분석(Braun \& Clarke, 2006)을, 복잡계이론으 로 축구재능발달을 해석하기 위하여 은유적 분석(Youn \& Chai, 2005)을 활용하였다.

주제분석은 원자료의 패턴 도출을 목표로 추출된 자료의 의미 분석 과정의 거시적 맥락을 중시한다. 본 연구에서는 자료와 익숙해지기, 초기코드생성, 주제탐색, 주제검토, 주 제선정, 최종검토의 주제분석 6단계(Kwon, 2020; Shin et al., 2013)를 적용해 자료를 분석하였다. 주제분석으로 도 출된 결과는 은유적 분석으로 해석하였다. 은유적 분석은 거시적 변화의 패턴과 구성요소의 상호작용을 분석시기와 변화주체를 시스템 관점에서 정리하는 방법이다(Youn \& 
Chai, 2005). 복잡계이론에서 은유적 분석은 무질서한 대 상이나 현상을 직관적으로 통찰하기 위한 방법으로 활용된 다(Kim, 2009b; Lee \& Jang, 2004; Shim et al., 2002; You, 2006).

\section{결과 및 논의}

축구재능발달 단계를 구분하기 위하여 복잡계이론의 분 석 틀을 토대로 수집한 축구재능발달 자료에 대한 은유적 분 석을 진행하였다. 복잡계이론의 구성개념과 잠재주제를 축 구재능발달 단계의 초기코드와 잠재주제로 해석한 결과, 축 구재능발달 단계는 잠재된재능 단계, 수월성기반재능계발 단계, 축구화된재능 단계, 축구재능도약 단계, 축구재능자 기화 단계로 〈Table 5〉와 같이 구분된다.

Table 5. Football talent development as a complexity theory

\begin{tabular}{|c|c|c|c|}
\hline \multicolumn{2}{|c|}{ Complexity theory } & \multicolumn{2}{|c|}{ Football talent development } \\
\hline Potential theme & Concepts & Initial code & Potential theme \\
\hline \multirow{3}{*}{$\begin{array}{l}\text { environment of } \\
\text { complexity }\end{array}$} & sensitive & physical condition & \multirow{3}{*}{ potential talents } \\
\hline & $\begin{array}{l}\text { dependency to } \\
\text { initial }\end{array}$ & $\begin{array}{c}\text { physical activity } \\
\text { preference }\end{array}$ & \\
\hline & $\begin{array}{c}\text { non- } \\
\text { equilibrium }\end{array}$ & change of environment & \\
\hline \multirow{3}{*}{$\begin{array}{l}\text { feedback } \\
\text { structure }\end{array}$} & \multirow{2}{*}{$\begin{array}{l}\text { positive } \\
\text { feedback }\end{array}$} & skill mastery & \multirow{3}{*}{$\begin{array}{c}\text { excellence based } \\
\text { talents } \\
\text { development }\end{array}$} \\
\hline & & thought of football & \\
\hline & coevolution & $\begin{array}{l}\text { relationship with } \\
\text { significant others }\end{array}$ & \\
\hline \multirow{3}{*}{$\begin{array}{c}\text { self- } \\
\text { organizationity }\end{array}$} & self- & skill fractionation & \multirow{3}{*}{$\begin{array}{c}\text { footballizational } \\
\text { talents }\end{array}$} \\
\hline & organization & football flow & \\
\hline & $\begin{array}{l}\text { dissipative } \\
\text { structure }\end{array}$ & growth experience & \\
\hline \multirow{3}{*}{$\begin{array}{l}\text { critical } \\
\text { condition }\end{array}$} & fluctuation\& & $\begin{array}{l}\text { overcoming crisis } \\
\text { experience }\end{array}$ & \multirow{3}{*}{$\begin{array}{l}\text { football } \\
\text { to takeoff }\end{array}$} \\
\hline & & performance scaffolding & \\
\hline & critical point & performance takeoff & \\
\hline \multirow{3}{*}{$\begin{array}{c}\text { emerge } \\
\text { phenomenon }\end{array}$} & emergence & $\begin{array}{l}\text { manifestation of } \\
\text { performance } \\
\text { personalization }\end{array}$ & \multirow{3}{*}{$\begin{array}{l}\text { personalization } \\
\text { of football } \\
\text { talents }\end{array}$} \\
\hline & clf_cimilaritu & performance evolution & \\
\hline & & condition maintenance & \\
\hline
\end{tabular}

복잡계이론을 토대로 구분한 축구재능발달 단계의 구체 적 특징은 다음과 같다.

\section{환경복잡성; 잠재된재능 단계}

환경복잡성은 초기조건민감성과 비평형성으로 구성된 다. 초기조건민감성은 초기의 혼돈이 결과 예측을 어렵게 만드는 현상으로, 축구재능발달 초기인 운동 시작단계는 신 체조건의 영향이 상대적으로 크다. 신체조건에 따른 발달 양상 차이를 $\mathrm{A}$ 는 다음과 같이 설명한다.

육상에서도 단거리보다는 장거리 중장거리 쪽 체력을 요구하는 중 장거리를 했었고, 워낙 다른 친구들보다 운동신경이 좋았기 때문에

...(중략)...그 뒤에 축구를 다시 시작하게 되었죠(A).

초기조건의 미묘한 차이는 결과 단계에 이르러 극명한 차 이로 나타나는데(Lozenz, 1972), 이는 스포츠재능에서도 예외는 아니다. 스포츠재능은 재능발달 초기 신체활동을 선 호하는 성향으로 발현되는데, $\mathrm{K}$ 는 신체활동 선호를 다음과 같이 설명한다.

방과 후에도 친구 집에 가서 축구하고 놀았어요. 어디에서 무엇을 해도 축구를 했는데, ...(중략)...신기한 게 제가 축구교실을 안 나가 고 빼먹고 친구 집에서 놀 때도 축구를 하면서 놀았거든요(K).

신체조건을 기반으로 한 신체활동 선호는 재능발달 초기 발현되는 특정 영역 선호(Bloom, 1985)에 해당한다. 신체 조건은 시기에 따라 영향이 달라지는 스포츠영재(Yun, 2010)이지만, 재능발달 초기 미세한 차이는 발달의 완성기 에 이르면 확연하게 다른 결과(You, 2006)로 연결된다. 이 처럼 복잡계이론의 초기조건민감성은 축구재능발달 단계에 서 신체조건과 신체활동 선호로 해석된다.

비평형성은 기존의 질서가 붕괴되어 복잡성이 증가한 상 태로, 선수생활 시작과 동시에 진행되는 급격한 환경 변화 에 따른 평형성 붕괴와 연결된다. 선수생활 시작으로 인한 환경의 격변을 $\mathrm{S}$ 는 다음과 같이 설명한다.

선생님께서 축구 한번 하자고 하셔서 부모님이랑 상담하고 바로 시 작하게 되었죠. 상담이 끝나고 바로 부모님은 이불이랑 챙겨서 합숙 소 갈 준비를 다해주셨어요(S)

선수입문기 합숙생활은 보호자와 분리되면서 환경의 불 
안정성을 가중시킨다. 이러한 초기조건의 차이는 이후 발생 하는 차이에서 나타나는 복잡성 증가(Im \& Park, 2012)와 체계에 혼란을 야기해 체계의 질서를 변화시킨다(Youn \& Chai, 2005). 이처럼 복잡계이론의 비평형성은 축구재능 발달 단계에서 환경변화로 해석된다.

이상을 종합하면 환경복잡성의 초기조건민감성과 비평 형성은 축구재능발달 단계에서 신체조건, 신체활동 선호와 환경변화로 해석된다. 또한 복잡계이론의 환경복잡성은 축 구재능발달 단계에서 운동에 적합한 신체조건과 신체활동 을 선호하는 경향이 축구에 적합한 환경과 결합되어 있는 잠 재된재능 단계로 설명할 수 있다.

\section{환류구조; 수월성기반재능계발 단계}

환류구조는 양의 환류와 공진화로 구성된다. 양의 환류 는 체계에 긍정적 에너지가 누적되는 과정으로, 이 단계는 축구선수가 되기 위해 훈련을 누적하며 성장하는 과정에 해 당한다. 훈련 누적에 따른 경기력 향상을 S는 다음과 같이 설명한다.

윙백 볼 때는 크로스 연습 많이 했고, 미드필더 때는 슈팅 연습 많이 했어요. 초등학교, 중학교 때는 훈련양이 진짜 많았거든요. 운동하 고 들어와서 밥 먹고 자고 다시 나가고 그랬었는데, 그때는 그게 당 연하다고 생각했었어요(S).

기술숙달은 재능발달과정(Weissensteiner et al., 2009)의 필요충분조건이다. 선수가 되기 위한 반복적 숙달 과정(Kim, 2009a)은 축구선수가 되기 위한 노력(Yun, 2015)과정이다. 축구선수 성장 과정에서 노력하는 태도의 의미를 $\mathrm{K}$ 는 다음과 같이 설명한다.

저는 항상 축구생각을 하면서 지냈어요 ...(중략)... 경기 중에 일어 나는 상황에 어떻게 할 것인가에 대한 답을 내기 전에 그런 거를 동 작으로 막 해봐요(K).

축구에 대한 지속적인 생각과 몰입은 궁극적으로 기술의 학습능력(Yun, 2011)에 영향을 미치고, 축구 기술숙달 속 도가 빨라지면 축구에 몰입이 강해지는 선순환(You, 2006) 을 형성하게 된다. 이처럼 복잡계이론의 양의 환류는 축구 재능발달 단계에서 기술숙달과 축구생각으로 해석된다.

공진화는 개체와 체계 사이의 보완성이 발생하는 구조로,
축구선수는 성장 과정에서 동료와 경쟁하거나 의지하면서 공생하게 된다. 선수의 성장 과정에서 나타나는 동료와 공 생을 $\mathrm{A}$ 는 다음과 같이 설명한다.

팀이 전체적으로 어느 정도는 실력이 좋은 친구들이었기 때문에 서 로 간에 경쟁을 하기도 하지만, 또 어떤 때는 서로 칭찬도 해주고.. (중략)...서로를 의지할 수 있는 친구들이었어요(A).

선수가 성장하기 위해서는 지도자는 물론 동료와 소통해 야 한다(Gould et al., 2002). 여기에 자기 자신과의 소통 (Yun, 2017)이 강조되고 있다. 이러한 상호 소통을 통한 시 너지효과(Lee \& Jang, 2004)에서 동료나 지도자의 영향은 크다. 선수의 성장 과정에서 지도자 역할의 중요성을 $\mathrm{W}$ 는 다음과 같이 설명한다.

더 다독여주고, 더 잘한다하면서 승패보다는 저희가 잘 할 수 있게, ...(중략)... 저희가 느끼고 더 잘할 수 있게 만들어 주셨어요. 제가 최고 존경하는 감독님이세요. 여태까지 계신분들 중에( $\mathrm{W})$.

선수의 성장 과정이나 결과에 있어 지도자의 영향력은 막 대하다(Holt \& Dunn, 2004). 동시에 지도자는 선수 경험 의 핵심적(Fraser-Thomas \& Côté, 2009)경로이기도 하 다. 따라서 지도자와 신뢰를 형성해 성장하는 선수는 지도 자의 지지와 체계의 상호 보완 속에서 안정적인 성장(Shim et al., 2002) 가능성이 크다. 이처럼 복잡계이론의 공진화 는 축구재능발달 단계에서 주요타자와 관계로 해석된다.

이상을 종합하면 환류구조의 양의 환류와 공진화는 축구 재능발달 단계에서 기술숙달, 축구생각과 주요타자와의 관 계로 해석된다. 또한 복잡계이론의 환류구조는 축구재능발 달 단계에서 몰입한 기술숙달과 이 과정에서 형성되는 주요 타자와 관계인 수월성기반재능계발 단계로 설명할 수 있다.

\section{자기조직성; 축구화된재능 단계}

자기조직성은 자기조직화와 분산구조로 구성된다. 자기 조직화는 체계에 에너지가 누적되면서 스스로 구조화되는 특징으로, 이 단계에 이르면 축구선수가 축구를 위해 노력 한 성과가 경기력으로 발현되기 시작한다. 노력의 결과가 경기력으로 발현되는 상황을 $\mathrm{K}$ 는 다음과 같이 설명한다.

볼 컨트롤 이런 것도 따지고 보면 머리를 쓰는 축구죠. 전에는 공을 
잡는 일만 생각했는데, 이제 공이 올 때 주위에 누가 있는지 확인을 하고, 공이 왔을 때 이 수비가 예측하는 반대의 컨트롤이나 플레이 를 하는 생각이 들었어요(K).

기술이 숙달되면 선수는 해당 종목에서 요구되는 보편적 기술수준(Shin et al., 2013)을 내재화한다. 이러한 숙달된 기술 조직화(Byun, 2011; Gell-Mann, 1995)과정에 이르 면 훈련은 물론 일상에서도 축구에 몰입한다. $\mathrm{H}$ 는 축구몰입 을 다음과 같이 설명한다.

수비할 때 이걸 뭐 나는 맨투맨한테는 안 뚫려아겠다는 생각을 항상 가지고 있고, 운동할 때가 아니어도 수비할 때 생각이 들어 뭘 해도 항상 ㄸㄸㅀ리지 않으려고 했던 게 있었어요(H).

축구선수의 몰입은 목표의식과 결합되어 기술분화를 거 치면서 축구환경에 적응해 두각을 나타낸다(Shin et al., 2013). 이처럼 복잡계이론의 자기조직화는 축구재능발달 단계에서 기술분화와 축구몰입으로 해석된다.

분산구조는 체계에 에너지가 지속적으로 유입되면서 형 성되는 구조로, 이 단계에 이르면 축구선수는 환경과 상호 작용하고 환경에 적응하면서 성장한다. 선수로 성장하는 과 정을 $\mathrm{W}$ 는 다음과 같이 설명한다.

올림픽이나 월드컵 갔던 친구들도 거의 대부분 다 알고, 제가 경험 하지 못한 수준 높은 축구를 많이 했었죠. ...(중략)... 함께 1년 반 정도 있다 보니 저도 자신감 붙고 했던 거같아요. 그게계기가 컸어 요(W).

선수의 성장 환경은 다양한데 특히 선수의 경기나 도약 경험(Yun \& Jeon, 2013)은 선수의 질적 성장과 연결된다. 동시에 선수의 성취 경험(Connaughton et al., 2010)은 외부의 에너지 유입으로 인한 불연속적 성장(Youn \& Chai, 2005)의 계기가 되기도 한다. 이러한 특징은 운동발 달의 비선형성(Kim, 2013)을 보여준다. 이처럼 복잡계이 론의 분산구조는 축구재능발달 단계에서 성장경험으로 해 석된다.

이상을 종합하면 자기조직성의 자기조직화와 분산구조 는 축구재능발달 단계에서 기술분화, 축구몰입과 성장경험 으로 해석된다. 또한 복잡계이론의 자기조직성은 축구재능 발달 단계에서 축구에 몰입한 기술분화를 기반으로 선수로 서 성장하는 축구화된재능 단계로 설명할 수 있다.

\section{임계조건; 축구재능도약 단계}

임계조건은 요동과 섭동, 임계점으로 구성된다. 요동과 섭동은 체계 내외부의 급격한 에너지 변화로, 이 단계에 이 르면 축구선수는 지금까지와는 다른 심각한 위기에 직면하 게 되고 이를 극복한다. $\mathrm{A}$ 는 위기 극복 경험을 다음과 같이 설명한다.

위기에서도 멘탈에서 무너지지 않고 굉장히잘 버텨줘서...(중략)... 지금까지와는 비교도 안되게 정말 힘들었는데, 오뚜기죠. 오뚜기 정신, 넘어져도 일어나고 어떻게든 버텨내겠다는 생각으로 지내다 보니 위기가 끝나 있었어요(A).

선수는 역경을 극복하면서 극복한 역경의 크기만큼 성장 한다(Kim \& Yun, 2016). 선수에게 급격한 위험은 체계의 급격한 요동이며, 이러한 요동은 에너지의 누적 결과이다 (Abbott et al., 2005). 이러한 역경에서 주요타자의 지지 는 적응적 태도 형성에 촉매가 되기도 한다(Kim \& Yun, 2016). 환경적응 과정에서 주요타자의 영향을 W는 다음과 같이 설명한다.

감독님 바뀌시고 되게 힘든 것도 막 되게 힘들게 운동을 시키시는 걸로 유명하잖아요. 근데 그게 저한테 맞았던 거 같아요. 힘들어도 선수 몸 관리가 몸 상태가 끌어올라오니까 저한테는 $\mathrm{O}$ 감독님이 계 시면서부터 제가 또 많이 성장했죠(W).

내부의 안정성은 내·외부의 요동으로 붕괴되고, 이러한 붕괴가 섭동(Whitesides \& Ismagilov, 1999)의 원인이 되기도 한다. 섭동은 환경 변화에 대한 적응과정의 역동성 으로, 체계에 에너지가 누적되어 에너지 균형의 급격한 변 화 순간(Youn \& Chai, 2005)이다. 이러한 과정을 거치면 서 선수의 경기력은 불연속적 도약인 비계를 경험한다. 이 처럼 복잡계이론의 요동과 섭동은 축구재능발달 단계에서 위기극복경험과 비계환경으로 해석된다.

임계점은 체계의 불안정성이 고조되면서 특정현상이 발 현되는 특이점으로, 이 단계에 이르면 선수의 경기력은 특 이점을 지나면서 급격한 도약을 이룬다. 선수로 경기력 특 이점 도달 경험을 $\mathrm{H}$ 는 다음과 같이 설명한다.

경기를 꾸준히 뛰다보니까 어느 순간 마음먹은 대로 되는 거예요. 차분해야 될 상황에서 차분해도 되더라구요. ...(중략)... 상대가 모 두 보이고, 잡고 보고 줘도 되고, 그렇게 해도 압박이 들어오는 상황 
을 피할 수 있더라구요. 그리고는 완전 자신이 생겼어요(H).

선수의 경기력 향상을 위한 노력은 축구 시작 시점부터 특이점 직전까지 에너지로 누적되어 체계의 불안정성 (Ruelle \& Takens, 1971)이 극대화된 상태이다. 누적된 에너지는 임계점에 이르면 경기력 상전이(Shin et al., 2013)로 나타난다. 이처럼 복잡계이론의 임계점은 축구재 능발달 단계에서 경기력 도약으로 해석된다.

이상을 종합하면 임계조건의 요동과 섭동, 임계점은 축 구재능발달 단계에서 위기극복경험, 비계환경과 경기력 도 약으로 해석된다. 또한 복잡계이론의 임계조건은 축구재능 발달 단계에서 위기 경험과 극복을 통한 특이점에서 축구재 능의 우화(旸化)인 축구재능도약 단계로 설명할 수 있다.

\section{창발현상; 축구재능자기화 단계}

창발현상은 창발과 자기유사성으로 구성된다. 창발은 구 성요인의 시너지가 산출물로 나타나는 현상으로, 이 단계에 이르면 임계점을 지나면서 나타난 자신에 특화된 축구재능 이 안정적으로 발현된다. 자기화 된 경기력의 의미를 $\mathrm{A}$ 는 다음과 같이 설명한다.

내 별명이 뭔 줄 알아요? 파워레인저예요. ...(중략)... 사람들이 나 를 봤을 때 어떤 이미지인가, 나만이 가지는 다른 선수와 완전히 차 별화되는 그거잖아요. 볼 이쁘게 차는(A).

선수의 자기화(Shin et al., 2013)된 경기력은 성장 과정 이 누적된 결과의 특수성이다. 이처럼 다른 대상과 차별화 되는 특수성과 특수성 기반의 산출물은 창발에 해당한다 (Kim, 2009a). 이처럼 복잡계이론의 창발은 축구재능발달 단계에서 경기력 자기화의 발현으로 해석된다.

자기유사성은 프랙탈 구조의 반복적 발생으로, 이 단계 에 이르면 선수는 창발을 통해 나타난 자기화 된 경기력을 경기에서 안정적으로 발현한다. 경기력 자기화의 발현 의미 를 $\mathrm{S}$ 는 다음과 같이 설명한다.

상대팀 마다 다르게 플레이해요. 투톱인 경우에는 사이에서 조율하 면서 도와주고, 원톱일 경우에는 앞에 나가서 미리 패스가 못 들어 오게 차단해요. 상대팀에 따라 그때그때 다르게 해요. 이렇게 해야 경기를 할 수 있어요(S).

선수의 경기 적응 과정은 실천지능(Yun, 2009)의 발현
과 기복 없는 경기력 측면에서 자기유사성(Lee \& Jang, 2004)으로 연결되어 경기력 진화가 나타난다. 자기유사성 은 유사한 패턴의 자기 반복적 발현 구조(Im \& Park, 2012)이다. 안정적 경기력 발현을 위한 적응과 기복 없는 플레이를 $\mathrm{H}$ 는 다음과 같이 설명한다.

멘탈 관리를 많이 해요. 내가 조금 어디가 불편해도 크게 신경쓰지 않고, 좋아도 좋은 생각을 하지 않아요. 그러면 기복이 줄어요...(중 략)... 내가 아무리 안 좋아도, 아무리 좋아도 생각하지 말자. 그런 생각이 몸에 베어 있는 거 같아요( $(\mathrm{H})$.

컨디션은 본질적으로 자기지각(Yun, 2017)이다. 이는 자신이 바라본 자신이기 때문에 주관적이지만 지각의 결과 가 다시 지각으로 환류되는 자기반복 구조를 띠고 있다. 자 기유사성에 이르면 자신의 컨디션을 원하는 방향으로 조절 할 수 있게 된다. 이처럼 복잡계이론의 자기유사성은 축구 재능발달 단계에서 경기력 진화와 컨디션 자기조절로 해석 된다.

이상을 종합하면 창발현상의 창발과 자기유사성은 축구 재능발달 단계에서 경기력 자기화의 발현, 경기력 진화와 컨디션 자기조절로 해석된다. 또한 복잡계이론의 창발현상 은 축구재능발달 단계에서 자기화를 기반으로 진화된 경기 력을 원하는 방향으로 조절하는 축구재능자기화 단계로 설 명할 수 있다.

\section{결론 및 제언}

복잡계이론을 기반으로 축구재능발달을 해석한 본 연구 의 결론은 다음과 같다.

첫째, 복잡계이론를 주제로 한 연구를 토대로 잠재주제 를 도출하여 복잡계이론의 분석 틀을 추출하였다. 분석 틀 도출 과정에서 복잡계이론 특징 중 축구재능발달 단계에서 나타나는 시간의 흐름, 순차적 발달과정, 구성요소 상호 간 의 융합적 과정의 반영 가능성을 고려하였다. 복잡계이론과 축구재능발달 단계의 특징을 종합한 결과 잠재주제로 환경 복잡성, 환류구조, 자기조직성, 임계조건, 창발현상을 선정 하였다. 이를 토대로 축구재능발달 단계 해석을 위한 분석 틀을 구조화하였다.

둘째, 복잡계이론의 분석 틀인 잠재주제와 구성개념으로 축구재능발달 단계를 해석하였다. 복잡계이론의 잠재주제 
인 환경복잡성은 잠재된재능 단계, 환류구조는 수월성기반 재능계발 단계, 자기조직성은 축구화된재능 단계, 임계조건 은 축구재능도약 단계, 창발현상은 축구재능자기화 단계로 해석하였다. 복잡계이론의 구성개념은 축구재능발달 단계 의 초기코드로 다음과 같이 해석된다. 환경복잡성의 초기조 건민감성과 비평형성은 축구재능발달 단계에서 신체조건과 신체활동 선호, 환경변화이다. 환류구조의 양의 환류와 공 진화는 축구재능발달 단계에서 축구생각과 기술숙달, 주요 타자와의 관계이다. 자기조직성의 자기조직화와 분산구조 는 축구재능발달 단계에서 기술분화와 축구몰입, 성장경험 이다. 임계조건의 요동과섭동, 임계점은 축구재능발달 단계 에서 위기극복경험과 비계환경, 경기력 도약이다. 창발현상 의 창발과 자기유사성은 축구재능발달 단계에서 경기력 자 기화의 발현, 경기력 진화와 컨디션 자기조절이다.

셋째, 축구재능은 잠재된재능, 수월성기반재능계발, 축구 화된재능, 축구재능도약, 축구재능자기화까지 단계를 거치 면서 발달한다. 축구재능발달 단계는 〈Fig 2〉로 요약된다.

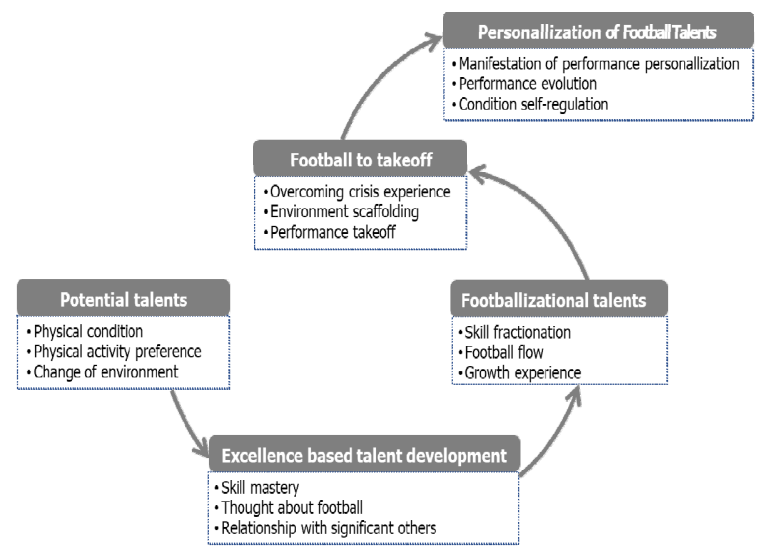

Fig 2. Football talent development stages

축구재능발달 단계에서 잠재된재능 단계는 운동에 적합 한 신체조건과 신체활동을 선호하는 경향에 축구에 적합한 환경으로 변화가 결합된 상태이다. 이어지는 수월성기반재 능계발 단계는 주요타자와 적절한 관계를 형성하면서 축구 에 몰입해 경기력을 숙달시키게 된다. 축구화된재능 단계에 서는 축구에 몰입한 기술분화를 기반으로 선수로 성장을 경 험한다. 축구재능도약 단계에서는 위기 경험과 극복을 통한 특이점에 도달한다. 마지막으로 축구재능자기화 단계에서 는 자기화를 기반으로 진화된 경기력을 원하는 방향으로 조
절할 수 있게 된다.

연구 결과와 연구 진행 과정을 토대로 후속연구에 다음과 같이 제언한다.

첫째, 축구재능발달 단계에 대한 관심의 확장이 필요하 다. 발달의 단계에 대한 이해는 발달의 전 과정에 대한 통합 적 이해를 제공한다. 본 연구에서는 복잡계이론을 도입하여 축구재능발달 단계를 설명하였다. 복잡계이론은 축구재능 발달 단계는 물론 다른 종목의 재능발달 단계를 설명하는 틀 로 활용이 기대된다. 복잡계이론은 스포츠심리학 연구에서 익숙하지 않은 주제로, 축구재능발달 설명을 토대로 이해하 는데 어려움이 있다. 향후 스포츠 재능발달 단계를 설명할 수 있는 이론적 토대를 발굴하고 이를 스포츠 재능발달 단계 설명에 활용하기 위한 연구를 기대한다. 동시에 복잡계이론 의 구조를 활용한 스포츠 재능발달 단계를 주제로 한 후속연 구를 기대해본다.

둘째, 축구재능발달 단계별 특징을 구체화할 수 있을 것 이다. 본 연구에서는 축구재능발달 분석 틀로 복잡계이론을 도입하여 축구재능발달의 단계를 잠재된재능, 수월성기반 재능계발, 축구화된재능, 축구재능도약, 축구재능자기화로 구획하였다. 본 연구의 결과, 재능발달 단계(Ericsson et al., 1993; Shin et al., 2013), 축구재능발달과업(Yun, 2013) 등은 발달 단계로 추정되고 있다. 이러한 축구재능발 달 단계별 구체적 특징, 각 다른 단계와 차별화되는 각 단계 의 특수성은 물론 다른 발달단계 이론과 비교를 통한 축구재 능발달 단계 검토 등의 연구를 수행할 수 있다. 축구재능발 달 단계별 발달 특징에 대한 깊이 있는 이해가 진행된다면, 축구선수 발달을 위한 훈련프로그램 구성의 기초자료로 활 용이 기대된다.

셋째, 축구선수재능발달 프로그램 개발에 활용이다. 대 한축구협회나 아시아축구연맹, 국제축구연맹에서 유소년 을 위한 축구재능발달 프로그램 개발과 보급 사업이 지속되 고 있다. 이러한 사업을 통하여 유소년 축구재능 발달 촉진 을 위한 개별 프로그램은 다양화되었다. 반면 개별 프로그 램 중심으로 재능발달 논의가 진행되어 발달과 발달 단계에 대한 통합적 이해는 상대적으로 제한되어 왔다. 축구선수의 재능발달 단계에 대한 통합적 이해 기반의 개별 프로그램은 프로그램 적용의 효율을 향상시킬 것이다.

본 연구가 축구재능발달 단계에 대한 통합적 이해에 기여 하는 동시에, 축구계의 축구재능발달 프로그램 개발 자료로 활용되기를 기대해본다. 


\section{참고문헌}

Abbott, A., Button, C., Pepping, G., \& Collins, D. (2005). Unnatural selection: Talent identification and development in sport. Nonlinear Dynamics Psychology \& Life Sciences, 9(1), 61-88.

Arthur, W. B. (1999). Complexity and the economy. Science, 284(5411), 107-109.

Bloom, B. S. (1985). Developing talent in young people. NY: Ballantine Books.

Braun, V. \& Clarke, V. (2006). Using thematic analysis in psychology. Qualitative Research in Psychology, 3(2), 77-101.

Burgess, D. \& Naughton, G. A. (2010). Talent development in adolescent team sports: A review. International Journal of Sports Physiology and Performance, 5, 103-116.

Byun, C. J. (2011). Emergence and coevolution in pollock's drip painting: Based on complex system theory. Journal of Contemporary Art Studies, 15(1), 49-90.

Choi, M. Y. \& Park, H. G. (2007). Overview of complexity. Physics and High Technology, 16(10), 2-6.

Chung, O. B. (2001). Adult development and aging. Seoul: Kyoyookbook.

Chung, O. B. (2004). Developmental Psychology. Seoul: Hakjisa.

Connaughton, D., Hanton, S., \& Jones, G. (2010). The Development and maintenance of mental toughness in the world's best performers. The Sport Psychologist, 24(2), 168-193.

Côté, J. (1999). The influence of the family in the development of talent in sport. The Sport Psychologist, 13(4), 395-417.

Crain, W. (2011). Theories of development (5thed). (Song, K. Y. \& Yoo, B. H. Eds). Seoul: Sigmapress.

Durand-Bush, N. \& Salmela, J. H. (2002). The development and maintenance of expert athletic performance: perceptions of world and olympic champions. Journal of Applied Sport Psychology, 14(3), 154-171.

Ericsson, K. A., Krampe, R., \& Resch-Romer, C. (1993). The role of deliberate practice in the acquisition of expert performance. Psychological Review, 100(3), 363-406.

Erikson, E. H. (1964). Insight and responsibility. NY: W. W.
Norton.

Fraser-Thomas, J. \& Côté, J. (2009). Understanding adolescents' positive and negative developmental experiences in sport. The Sport Psychologist, 23(1), 3-23.

Gagné, F. (1985). Giftedness and talent: Reexamining a reexamination of the definitions. Gifted Child Quarterly, 29(3), 103-112.

Gagné, F. (2004). Transforming gifts into talents: The DMGT as a developmental theory. High Ability Studies, 15(2), 119-147.

Gagné, F. (2010). Motivation within the DMGT 2.0 framework. High Ability Studies, 21(2), 81-99.

Gell-Mann, M. (1995). The quark and the jaguar: Adventures in the simple and the complex. NY: Owl Books.

Gould, D., Dieffenbach, K., \& Moffett, A. (2002). Psychological characteristics and their development in olympic champions. Journal of Applied Sport Psychology. 14(3), 172-204.

Helsen, W. F., Hodges, N. J., Winckel, J. V., \& Starkes, J. L. (2000). The roles of talent, physical precocity and practice in the development of soccer expertise. Journal of Sports Sciences, 18(9), 727-736.

Holt, N. L. \& Dunn, J. G. H. (2004). Toward a grounded theory of the psycholosocial competencies and environmental conditions associated with soccer success. Journal of Applied Sport Psychology, 16(3), 199-219.

Im, M. J. \& Park, M. H. (2012). A study on fashion design applied with the characteristics of chaos theory. Journal of Digital Design 12(2), 439-448.

Jeong, J. H. \& Park, S. G. (1999). Applicability for organizational environment study of complexity theory. Korean Public Administration Quarterly, 11(2), 267-286.

$\mathrm{KFA}(2014)$. 골든에이지 훈련 프로그램. 대한축구협회. $\mathrm{KFA}(2019)$. 지도자교육 규정. 대한축구협회.

Kim, H. J. \& Yun, Y. K. (2016). The posttraumatic growth process of volleyball players. Korean Journal of Sport Science, 27(3), 666-676.

Kim, K. H. (2008). Complexity, chaos, and evolutionary rationality of policy: Focused on the policy of the separation of dispensary from medical practice. Journal of Governmental Studies, 14(1), 139-178.

Kim, K. H. (2009a). A study on the usefulness and 
applicability of complexity theory in policy studies. Korean Journal of Public Administration, 47(2), 281-312.

Kim, K. H. (2009b). Complexity and self-organization of policy system: Focused on the policy of the separation of dispensary from medical practice. Korean Policy Studies Review, 18(4), 23-60.

Kim, S. J. (2013). motor learning and control (2nd ed). Seoul: Daehanmedia.

Kim, U. S., Choi, E. T., \& Lee, Y. S. (2002). Dreams come true: Youth training of football powerful nation. Seoul: KFA.

Kim, Y. S. \& Lee, M. C. (2007). Agent-based models as a modeling tool for complex adaptive policy and managerial problems. Korean Journal of Public Administration, 45(2), 25-49.

Kohlberg, L. (1963). The development of children's orientations toward a moral order: I. Sequence in the development of moral thought. Human Development, 6, 11-33.

Kwon, O. J. (2020). Meaning of participation in exercise with companion dog through photovoice. The Korean Journal of Physical Education, 59(1), 223-240.

Lee, J. K. (2014). Philosophy and complex system. Korea Academy of Complexity Studies 2014 spring symposium, 53-79.

Lee, J. S. (2009). Research methodology. Gyeonggi: Kyoyookbook.

Lee, K. M. \& Jang, S. H. (2004). Article: A case study on the relevance of complexity theory: On the focus of self-organization phenomenon of street cheer in the 『2002 the world cup』. Korean Society and Public Administration, 15(1), 355-378.

Lee, S. R. \& Sohn, Y. W. (2013). What are the strong predictors of academic achievement? - Deliberate practice and grit. The Korean Journal of School Psychology, 10(3), 349-366.

Lorenz, E. N. (1972). Predictability: Does the flap of a butterfly's wings in brazil set off a tornado in texas? American Association for the Advancement of Science, 1-3.

Mills, A., Butt, J., Maynard, I., \& Harwood, C. (2012). Identifying factors perceived to influence the development of elite youth football academy players. Journal Sports Science, 30(15), 1593 - 1604.
Orosz, R.., \& Mezo, F. (2015). Psychological Factors in the Development of Football-Talent from the Perspective of an Integrative Sport-Talent Model. Journal for the Education of Gifted Young Scientists, 3(1), 58-76.

Phillips, E., Davids, K., Renshaw, I., \& Portus, M. (2010). Expert performance in sport and the dynamics of talent development. Sports Medicine 40(4), 271-283.

Piaget, J. (1936). The origins of intelligence in children (MCook, trans). NY: International University Presss, 1974.

Renzulli, J. S. (1986). The three ring conception of giftedness: A developmental model for creative productivity. In R. J. Sternberg \& J. E. Davison (Eds.), Conception of giftedness (2ndEd.) (pp. 247-279). MA: Cambridge University Press.

Renzulli, J. S. (2003). Conceptions of giftedness and its relationship to the development of social capital. In $\mathrm{N}$. Colangelo and G. Davis (Eds.), Handbook of gifted education (3rd Ed.) (pp. 45-59). NY: Allyn and Bacon.

Ruelle, D. \& Takens, F. (1971). On the nature of turbulence. Communications in Mathematical Physics, 20(3), 167-192.

Ryu, K. U., Jung, J. W., Kim, Y. S., \& Kim, H. B. (2012). Qualitative research methods. Seoul: Pakyoung story.

Seong, C. H. (2009). Exploration on talents of exceptional performance in sport: Developmental perspective. The Korean Journal of Physical Education-Humanities and social sciences, 48(2), 159-170.

Shim, S. M., Ko, J. M., Han, C. S., \& Jung, Y. S. (2002). 2002 World-cup and social-curltureal change. Seoul: Samsung Economic Research Institute.

Shin, J. H., Min, J. Y., Cho, E. B., Jang, D. H., Jee, H. M., \& Yun, Y. K. (2013). Nature of giftedness and its development in the soccer: Based on implicit knowledge of korean youth national teams' players and coaches. Journal of Educational Psychology, 27(2), 431-452.

Singer, J. L. (1995). Mental processes and brain architecrure: Confronting the complex adaptive systems of human thought(An Overview). In H. J. Morowitz \& J. L. Singer (Ed.), The mind, the brain and complex adaptive systems. MA: Addison-Wesley.

Song, D. S. (2007). Discussion on giftedness by genetic and environmental factors in the intellectual abilities. Journal of Gifted/Talented Education, 17(2), 280-306.

Sternberg, R. J. (1996). What should we ask about 
intelligence?. American Scholar, 65(2), 205-217.

Sternberg, R. J. (1999). Successful intelligence: finding a balance. Trends in Cognitive Sciences, 3(11), 436-442.

Weissensteiner, J., Abernethy, B., \& Farrow, D. (2009). Towards the development of a conceptual model of expertise in cricket batting: a grounded theory approach. Journal of applied sport psychology, 21(3), 276-292.

Whitesides, G. M. \& Ismagilov, R. F. (1999). Complexity in chemistry. Science, 284(5411), 89-92.

You, Y. M. (2006). 'Complexity' of a 'simple' learning: complex learning systems through the lens of complexity sience. Andragogy Today: Interdisciplinary Journal of Adult \& Continuing Education, 9(2), 53-96.

Youn, Y. S. \& Chai, S. B. (2005). Complexity system introduction. Seoul: Samsung Economic Research Institute.

Yun, Y. K. \& Jeon, J. Y. (2012). Cross sectional tendency of football performance perception. Korean Journal of Physical Education, 51(2), 147-155.

Yun, Y. K. \& Jeon, J. Y. (2013). Surrounding environment for sport talents manifestation and probability of interaction between sport talents and surrounding environment for sport talented. Korean Journal of Sport Science, 24(2),
244-255.

Yun, Y. K. \& Kim, J. S. (2017). Validation examination for introduction of team performance conception in football. Korean Journal of Sport Science, 28(4), 994-1005.

Yun, Y. K. \& Lee, Y. S. (2006). Hierarchical importance and structure of factors in football performance. Korean Journal of Sport Psychology, 17(4), 87-100.

Yun, Y. K. (2009). Conception and applicative implication of practical intelligence in football player's tactics. Korean Journal of Sport Psychology, 20(2), 113-127.

Yun, Y. K. (2011). Sport talents for sport talented. Korean Journal of Sport Psychology, 22(4), 17-32.

Yun, Y. K. (2013). Developmental tasks for football talented in high school football players. Korean Journal of Sport Science, 24(4), 709-719.

Yun, Y. K. (2015). Football prformance approach drift and current affairs in aspect of intelligence. Korean Journal of Sport Science, 26(1), 163-173.

Yun, Y. K. (2017). Adoption of usability in condition questionnaire development. Korean Journal of Sport Science, 28(3), 739-749. 


\title{
복잡계이론 관점에서 본 축구재능발달 단계
}

\author{
강지훈 ${ }^{1}$, 윤영길 ${ }^{2}$ \\ ${ }^{1}$ 한국체육대학교 박사과정 \\ ${ }^{2}$ 한국체육대학교 교수
}

[목적] 본 연구는 복잡계이론을 토대로 축구재능발달 단계를 해석할 목적으로 진행하였다. [방법] 본 연구는 문헌연구와 심층면담을 통해 자료를 수집하였다. 문헌연구에서는 복잡계이론을 주제로 한 연구를 대상으로 복잡계이론의 특징을 추출하였으며, $\mathrm{K}$ 리그 선수 5 명을 대상으로 심층면담을 진행하였다. 수집된 자료는 주제 분석을 진행하였다. 축구재능발달의 초기코드와 잠재주제, 복잡계이론의 구성개념과 잠재주제는 은유적 분석 으로 해석하였다. [결과] 문헌연구 결과 복잡계이론의 분석 틀은 환경복잡성, 환류구조, 자기조직성, 임계조건, 창발현상으로 구성되었다. 문헌연구를 토대로 축구재능발달 단계를 해석하여 축구재능발달 단계를 잠재된재 능, 수월성기반재능계발, 축구화된재능, 축구재능도약, 축구재능자기화 단계로 구획하였다. 구체적으로 잠재 된재능 단계는 신체조건, 신체활동 선호와 환경변화로, 수월성기반재능계발 단계는 기술숙달, 축구생각과 주 요타자와의 관계로, 축구화된재능 단계는 기술분화, 축구몰입과 성장경험으로, 축구재능도약 단계는 위기극복 경험, 비계환경과 경기력 도약으로, 축구재능자기화 단계는 경기력 자기화의 발현, 경기력 진화와 컨디션 자기 조절로 구체화하였다. [결론] 복잡계이론을 토대로 해석한 축구재능발달 단계는 잠재된재능 단계, 수월성기반 재능계발 단계, 축구화된재능 단계, 축구재능도약 단계, 축구재능자기화 단계로 구분된다. 본 연구가 축구재능 발달 단계에 대한 이해를 증진시키는 동시에, 축구재능발달 프로그램의 기초자료로 활용되기를 기대해본다.

주요어: 축구재능발달 단계, 발달 단계, 축구재능, 축구재능발달, 복잡계이론, 축구 